\title{
A non-sense mutation in the putative anti-mutator gene adalalkA of Mycobacterium tuberculosis and $M$. bovis isolates suggests convergent evolution
}

\author{
Laurent X Nouvel ${ }^{1}$, Tiago Dos Vultos ${ }^{1}$, Eric Kassa-Kelembho², Jean Rauzier ${ }^{1}$ \\ and Brigitte Gicquel*1
}

\author{
Address: ${ }^{1}$ Unité de Génétique Mycobactérienne, Institut Pasteur, 28 rue du Dr. Roux, 75724 Paris Cedex, France and ${ }^{2}$ Laboratoire des \\ Mycobactéries, Institut Pasteur, Bangui, Central African Republic \\ Email: Laurent X Nouvel - x.nouvel@envt.fr; Tiago Dos Vultos - tvultos@pasteur.fr; Eric Kassa-Kelembho - ekassa@pasteur-bangui.org; \\ Jean Rauzier - jrauzier@pasteur.fr; Brigitte Gicquel* - bgicquel@pasteur.fr \\ * Corresponding author
}

Published: 16 May 2007

BMC Microbiology 2007, 7:39 doi:10.1186/1471-2180-7-39

This article is available from: http://www.biomedcentral.com/I47I-2180/7/39

(C) 2007 Nouvel et al; licensee BioMed Central Ltd.

This is an Open Access article distributed under the terms of the Creative Commons Attribution License (http://creativecommons.org/licenses/by/2.0), which permits unrestricted use, distribution, and reproduction in any medium, provided the original work is properly cited.

\begin{abstract}
Background: Previous studies have suggested that variations in DNA repair genes of W-Beijing strains may have led to transient mutator phenotypes which in turn may have contributed to host adaptation of this strain family. Single nucleotide polymorphism (SNP) in the DNA repair gene mutTI was identified in MDR-prone strains from the Central African Republic. A Mycobacteriumtuberculosis H37Rv mutant inactivated in two DNA repair genes, namely adalalkA and ogt, was shown to display a hypermutator phenotype. We then looked for polymorphisms in these genes in Central African Republic strains (CAR).

Results: In this study, 55 MDR and 194 non-MDR strains were analyzed. Variations in DNA repair genes adalalkA and ogt were identified. Among them, by comparison to M. tuberculosis published sequences, we found a non-sense variation in adalalkA gene which was also observed in $M$. bovis AF2I 22 strain. SNPs that are present in the adjacent regions to the amber variation are different in $M$. bovis and in $M$. tuberculosis strain.

Conclusion: An Amber codon was found in the adalalkA locus of clustered M. tuberculosis isolates and in M. bovis strain AF2 122. This is likely due to convergent evolution because SNP differences between strains are incompatible with horizontal transfer of an entire gene. This suggests that such a variation may confer a selective advantage and be implicated in hypermutator phenotype expression, which in turn contributes to adaptation to environmental changes.
\end{abstract}

\section{Background}

With more than 2 million deaths a year, tuberculosis (TB) remains a major public health problem. As one-third of the world's population is infected, Mycobacterium tuberculosis is probably the most widespread human pathogen and the number of $\mathrm{TB}$ cases is growing at a rate of $2 \%$ per year [1]. This bacterium is remarkably well-adapted to its host, in which it can persist for years without inducing symptoms. Despite its worldwide dissemination and presence in diverse host populations, the genetic variability of M. tuberculosis appears to be very low with the exception 
of hot spot regions in the genome that are associated with mobile elements [2-5].

Previous studies on W-Beijing family strains have identified variations in putative DNA repair genes (mutT2, mutT4 and ogt). These variations are found only in the $\mathrm{W}-$ Beijing family; they can therefore be considered to be specific markers of this family and suggest that a mutator phenotype, at least transient, may have contributed to the host adaptation of this family of strains [6].

Durbach et al. [7] co-inactivated DNA repair genes, namely ada/alkA and ogt, in strain H37Rv and showed that the resulting mutant displayed a mutator phenotype under nitrosative stress.

While studying the genetic diversity of $M$. tuberculosis isolates in the Central African Republic (CAR), we described an MDR-prone family characterized by a T family spoligotype and a synonymous variation in the DNA repair gene mutT1 [8]. This prompted us to screen our set of welldefined isolates from CAR $[8,9]$ by sequencing putative anti-mutator genes including ada/alkA to identify other variations that could be markers of relevant clinical strains.

Comparisons of CAR strain sequences with published " $M$. tuberculosis complex" genome sequences revealed an SNP common to these strains and M. bovis strain AF2122. This suggests either horizontal DNA transfer between $M$. bovis and $M$. tuberculosis CAR strains or convergent evolution. Medigue et al. and Denamur et al. [10,11] demonstrated horizontal transfer of DNA repair genes in E. coli. To determine whether there has been transfer between $M$. bovis and M. tuberculosis strains, we looked at polymorphism in the regions upstream and downstream from this common SNP by PCR sequencing. We provide evidence that this SNP may have occurred twice independently and might therefore be an example of convergent evolution.

\section{Results \\ Variations in the ada/alkA and ogt genes in a series of MDR isolates}

Variations in ada/alkA and ogt genes were assessed in fiftyfive MDR strains collected between 1993 and 2001 in CAR. PCR products corresponding to ada/alkA and those corresponding to ogt were obtained for each MDR CAR strain in our collection. Direct sequencing of PCR products revealed four variations in DNA repair genes: one in ogt and three in ada/alkA (table 1).

The ogt variant is a $\mathrm{C}$ to $\mathrm{G}$ substitution causing the replacement of a Threonine by a Serine at position 15 in Ogt, noted A CC $\rightarrow$ A GC (Thr15 $\rightarrow$ Ser). This variation is carried by three CAR isolates. It has been previously observed in other strains and considered to be characteristic of Haarlem strains $[6,12]$.

Nine strains carry an ACT $\rightarrow$ A $\underline{\text { AT }}($ Thr $337 \rightarrow$ Asn) variation, and five of these strains also display a TGG $\rightarrow$ TAG (Trp79 $\rightarrow$ AMBER) variation. This is the first report of a variant involving a nonsense codon in M. tuberculosis. This raised the question of whether such variations also occurred in non-MDR strains.

\section{Polymorphism of ada/alkA in a series of non-MDR strains (Table I)}

Using the same sequencing approach, we searched for the presence of the nonsense variation TGG $\rightarrow$ TAG (Trp79 $\rightarrow$ AMBER) and other ada/alkA or ogt polymorphisms in a set of 194 well-defined non-MDR strains isolated in CAR between April 15 th and August $15^{\text {th }} 1998$ from the cohort studied by Espinal et al. [9]: 138 of these isolates were found to carry sequence variations (Table 1 ). Twenty-four of the strains carry the ACT $\rightarrow$ AAT (Thr337 $\rightarrow$ Asn) variation, including three that also carry the TGG $\rightarrow$ T $\underline{A G}$ (Trp79 $\rightarrow$ AMBER).

We searched ada/alkA sequences in available "M. tuberculosis complex" genome sequences and found the TGG $\rightarrow$ TAG $($ Trp79 $\rightarrow$ AMBER) variation in M. bovis strain AF2122. The spoligotypes of the CAR isolates with the TGG $\rightarrow$ TAG (Trp79 $\rightarrow$ AMBER) variation indicate that they are Haarlem M. tuberculosis strains. This suggests that this Amber mutation has occurred independently in at least two different species of the "M. tuberculosis complex" or that it has been acquired by horizontal DNA transfer. To test these possibilities, we studied the polymorphisms of chromosomal regions flanking the TGG $\rightarrow$ TAG (Trp79 $\rightarrow$ AMBER) ada/alkA SNP.

We compared regions flanking the Amber variation in $M$. tuberculosis strains including (I) CAR isolates carrying the Thr337 $\rightarrow$ Asn variation with or without the Amber variant, (II) H37Rv, (III) CDC1551 and (IV) W-Beijing 210 and in M. bovis strains including (V) RCA isolates, (VI) strain AF2122 and (VII) BCG Pasteur. In addition to the ada/alkA gene variations previously found in MDR CAR strains, we identified two further SNPs affecting the ada/ alkA coding sequence: GCG $\rightarrow$ ACG (Ala $11 \rightarrow$ Thr) only found in W-Beijing210 and CT $\rightarrow$ $\rightarrow$ CTA (Leu269 $\rightarrow$ Leu) harboured by M. bovis AF2122 and BCG Pasteur. We also found six SNPs outside of the ada/alkA coding sequence: SNP1, SNP2 and SNP3 downstream from ada/alkA, and SNP4, SNP5 and SNP6 upstream from the gene (table 2). SNPs 2, 4, 5 and 6 were found in all strains except in

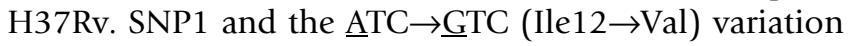
were found in all $M$. bovis strains but not in any CAR isolates of M. tuberculosis. The CTG $\rightarrow$ CTA $($ Leu269 $\rightarrow$ Leu) variation is present only in M. bovis AF2122 and BCG Pas- 
Table I: adalalkA variants

\begin{tabular}{|c|c|c|c|c|c|c|}
\hline \multirow[b]{2}{*}{$\begin{array}{l}\mathbf{N}^{\circ} \text { of } \\
\text { strains }\end{array}$} & \multirow{2}{*}{$\begin{array}{c}\text { ogt } \\
\text { Codon } 15\end{array}$} & \multicolumn{5}{|c|}{ adalalkA } \\
\hline & & $\begin{array}{c}\text { Codon } \\
\text { II }\end{array}$ & Codon 12 & Codon 79 & Codon 254 & Codon 337 \\
\hline & & \multicolumn{5}{|c|}{ among MDR } \\
\hline 41 & wt & wt & Wt & wt & wt & wt \\
\hline 3 & $\mathrm{ACC} \rightarrow \mathrm{AGC}(\mathrm{Thr} \mid 5 \rightarrow \mathrm{Ser})$ & & & & & \\
\hline 2 & wt & wt & 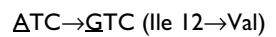 & wt & wt & wt \\
\hline 4 & wt & wt & Wt & wt & wt & $\mathrm{ACCT} \rightarrow \mathrm{AAT}(\mathrm{Thr} 337 \rightarrow$ Asn) \\
\hline \multirow[t]{2}{*}{5} & wt & wt & Wt & 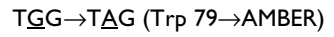 & wt & $\mathrm{A} \underline{\mathrm{C}} \mathrm{T} \rightarrow \mathrm{A} \underline{\mathrm{A}} \mathrm{T}(\mathrm{Thr} 337 \rightarrow \mathrm{Asn})$ \\
\hline & & \multicolumn{5}{|c|}{ among non-MDR } \\
\hline 56 & wt & wt & Wt & wt & wt & wt \\
\hline 105 & $\mathrm{ACC} \rightarrow \mathrm{AGC}($ Thr $15 \rightarrow$ Ser $)$ & wt & Wt & wt & wt & wt \\
\hline I & wt & wt & $\underline{\mathrm{ATC}} \rightarrow \underline{\mathrm{GTC}}(\mathrm{lle} \mathrm{I} 2 \rightarrow \mathrm{Val})$ & wt & wt & wt \\
\hline 7 & wt & wt & 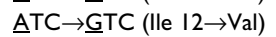 & wt & wt & wt \\
\hline 1 & wt & wt & $\overline{\mathrm{ATC}} \rightarrow \underline{\mathrm{G}} \mathrm{TC}(\mathrm{lle} \mid 2 \rightarrow \mathrm{Val})$ & wt & Pro CCC 254 Pro CCA & wt \\
\hline 21 & wt & wt & $-\mathrm{Wt}_{\mathrm{t}}$ & wt & wt & $\underline{\mathrm{ACT}} \rightarrow$ AAT $($ Thr $337 \rightarrow$ Asn) \\
\hline 3 & wt & wt & Wt & TGG $\rightarrow$ T $\underline{A G}(\operatorname{Trp} 79 \rightarrow$ AMBER) & wt & $\overline{\mathrm{A}} \underline{\mathrm{CT}} \rightarrow \mathrm{A} \underline{\mathrm{A} T}(\mathrm{Thr} 337 \rightarrow \mathrm{Asn})$ \\
\hline
\end{tabular}

wt: wild type $(\mathrm{H} 37 \mathrm{Rv})$

teur and SNP3 only in M. bovis AF2122. In contrast, CAR M. tuberculosis Amber variants also harbour the $\mathrm{A} \underline{\mathrm{CT}} \rightarrow \mathrm{A} \underline{\mathrm{AT}}$ (Thr337 $\rightarrow$ Asn) variation and do not carry SNP1 or SNP3, or codon 12 and 269 modifications. Therefore, DNA polymorphisms identified in CAR M. tuberculosis Amber variant isolates differ from those observed in $M$. bovis strain AF2122 (Table 2). This is not compatible with the occurrence of the Amber variation in both groups being a consequence of horizontal transfer and allelic replacement of the entire ada/alkA gene. It is therefore more likely that independent events are responsible for the appearance of this variation in the two species, thus suggesting convergent evolution.

\section{Spoligotypes of $M$. tuberculosis strains and relatedness}

Spoligotyping of all these CAR isolates has been reported in Nouvel et al. [8]. Spoligotype clusters were named by their Shared Type number according to the spoligotype database SpolDB3 [13]. We considered the distribution of CAR Amber variant isolates among the clusters. They were found in three different clusters: (I) "ST047" (composed of 50 strains of which only one carries the Amber variation), "ST316 minus spacer 13" (five strains, all carrying the Amber variant, four of them being MDR) and "ST316" (22 strains, two carrying the Amber variation). The ACT $\rightarrow$ AAT $($ Thr337 $\rightarrow$ Asn) variation alone (not associated with the Amber variant) is present in strains of clusters "ST047", "ST316", "ST312" and "ST312 minus spacers 42-43". These clusters share 93.47 to $98.4 \%$ spoligotype identity (Figure 1) and could reasonably be considered as a single family.

\section{Discussion}

In our collection of CAR isolates, the ada/alkA gene variant $\mathrm{A} \underline{\mathrm{CT}} \rightarrow \mathrm{A} \underline{\mathrm{AT}}$ (Thr337 $\rightarrow$ Asn) was found in 16 isolates, eight of which also carry the TGG $\rightarrow$ TAG $(\operatorname{Trp} 79 \rightarrow$ AMBER) variation. This suggests that the ACT $\rightarrow$ AAT $($ Thr337 $\rightarrow$ Asn) mutation appeared before the TGG $\rightarrow$ TAG $(\operatorname{Trp} 79 \rightarrow$ AMBER) mutation.

Moreover, strains carrying only the ACET $\rightarrow$ AAT (Thr337 $\rightarrow$ Asn) variation show spoligopatterns "ST047", "ST312", "ST314", "ST316", "ST312 without spacers 4243", or "ST314 without spacers 39". Strains carrying both $\mathrm{A} \underline{\mathrm{CT}} \rightarrow \mathrm{A} \underline{\mathrm{AT}} \quad(\mathrm{Thr} 337 \rightarrow$ Asn $) \quad$ and $\quad$ TGG $\rightarrow$ T $\underline{A G}$ (Trp79 $\rightarrow$ AMBER) belong to "ST047", "ST316" or "ST316 without spacer 13". All these Shared Types are similar and differ by a small number of spacers. The spoligopatterns of these 16 strains classify them into the Haarlem family (similar to ST047). However, the strains with ACT $\rightarrow$ AAT (Thr337 $\rightarrow$ Asn) variation with or without the TGG $\rightarrow$ T $\underline{A G}$ (Trp79 $\rightarrow$ AMBER) variation do not carry variations in ogt: this suggests they are all derived from an ancient Haarlem family strain before the appearance of the ogt variants. We propose a genealogy of strains showing a Haarlem spoligotype and carrying the Amber variation in the ada/alkA gene (Figure 2). Further studies will be necessary to assess whether these strains are an emerging cluster in CAR.

The Amber variation in ada/alka is also found in M. bovis strain AF2122. This Amber variation is absent from the two M. bovis strains isolated in CAR analysed in this study (identified as M. bovis by biochemical tests and confirmed 
Table 2: SNPs in the alkA region

\begin{tabular}{|c|c|c|c|c|c|c|c|c|c|}
\hline \multirow[b]{2}{*}{$\begin{array}{c}\text { SNP } \\
\text { position }^{a}\end{array}$} & \multicolumn{3}{|c|}{ Downstream region } & \multicolumn{5}{|c|}{$\leftarrow$ adalalkA } & \multirow{2}{*}{$\begin{array}{c}\text { Upstream } \\
\text { region }\end{array}$} \\
\hline & $\begin{array}{c}\text { SNPI } \\
\text { I471.218 }\end{array}$ & $\begin{array}{c}\text { SNP2 } \\
1471.659\end{array}$ & $\begin{array}{c}\text { SNP3 } \\
1477.028\end{array}$ & $\begin{array}{c}\text { Codon } 337 \\
\text { |478.108 }\end{array}$ & $\begin{array}{c}\text { Codon } 269 \\
\text { 1478.3 I2 }\end{array}$ & $\begin{array}{l}\text { Codon } 79 \\
1478.883\end{array}$ & $\begin{array}{l}\text { Codon } 12 \\
1479.085\end{array}$ & $\begin{array}{l}\text { Codon II } \\
\text { I479.088 }\end{array}$ & \\
\hline Strains & \multicolumn{9}{|c|}{ In CAR strains } \\
\hline $\begin{array}{c}\text { M.tb alkA } \\
79+337 \mathrm{c}\end{array}$ & wt & $\mathrm{C} \rightarrow \mathrm{T}$ & wt & $\mathrm{A} \underline{\mathrm{C}} \mathrm{T} \rightarrow \mathrm{A} \underline{\mathrm{A}} \mathrm{T}$ & wt & $\mathrm{T} \underline{\mathrm{G}} \rightarrow \mathrm{T} \underline{\mathrm{A} G}$ & wt & wt & $\begin{array}{c}\mathrm{T} \rightarrow \mathrm{C}, \mathrm{T} \rightarrow \mathrm{C}, \\
\mathrm{A} \rightarrow \mathrm{C}\end{array}$ \\
\hline $\begin{array}{l}\text { M.tb alkA } \\
337^{d}\end{array}$ & wt & $\mathrm{C} \rightarrow \mathrm{T}$ & wt & $\mathrm{A} \underline{\mathrm{C}} \mathrm{T} \rightarrow \mathrm{A} \underline{\mathrm{A}} \mathrm{T}$ & wt & wt & wt & wt & $\begin{array}{c}\mathrm{T} \rightarrow \mathrm{C}, \mathrm{T} \rightarrow \mathrm{C}, \\
\mathrm{A} \rightarrow \mathrm{C}\end{array}$ \\
\hline \multirow[t]{2}{*}{ M.bv CARe } & $\mathrm{C} \rightarrow \mathrm{T}$ & $\mathrm{C} \rightarrow \mathrm{T}$ & wt & wt & wt & wt & $\underline{\mathrm{ATC}} \rightarrow \underline{\mathrm{GT}} \mathrm{C}$ & wt & $\begin{array}{c}\mathrm{T} \rightarrow \mathrm{C}, \mathrm{T} \rightarrow \mathrm{C}, \\
\mathrm{A} \rightarrow \mathrm{C}\end{array}$ \\
\hline & \multicolumn{9}{|c|}{ in other strains } \\
\hline $\begin{array}{c}\text { M.bv } \\
\text { AF2I } 22\end{array}$ & $\mathrm{C} \rightarrow \mathrm{T}$ & $\mathrm{C} \rightarrow \mathrm{T}$ & $C \rightarrow-$ & wt & $\mathrm{CT} \underline{G} \rightarrow \mathrm{CT} \underline{\mathrm{A}}$ & $\mathrm{TGG} \rightarrow \mathrm{T} \underline{\mathrm{AG}}$ & $\underline{\mathrm{ATC}} \rightarrow \underline{\mathrm{GTC}}$ & wt & $\begin{array}{c}\mathrm{T} \rightarrow \mathrm{C}, \mathrm{T} \rightarrow \mathrm{C}, \\
\mathrm{A} \rightarrow \mathrm{C}\end{array}$ \\
\hline M. bv BCG & $\mathrm{C} \rightarrow \mathrm{T}$ & $\mathrm{C} \rightarrow \mathrm{T}$ & wt & wt & $\mathrm{CT} \underline{\mathrm{G}} \rightarrow \mathrm{CT} \underline{\mathrm{A}}$ & wt & $\underline{\mathrm{ATC}} \rightarrow \underline{\mathrm{GT}} \mathrm{C}$ & wt & $\begin{array}{c}\mathrm{T} \rightarrow \mathrm{C}, \mathrm{T} \rightarrow \mathrm{C}, \\
\mathrm{A} \rightarrow \mathrm{C}\end{array}$ \\
\hline M.tb 210 & wt & $\mathrm{C} \rightarrow \mathrm{T}$ & wt & wt & wt & wt & $\underline{\mathrm{ATC}} \rightarrow \underline{\mathrm{GTC}}$ & $\underset{G}{\mathrm{G} C G} \rightarrow \underline{A C}$ & $\begin{array}{c}\mathrm{T} \rightarrow \mathrm{C}, \mathrm{T} \rightarrow \mathrm{C}, \\
\mathrm{A} \rightarrow \mathrm{C}\end{array}$ \\
\hline $\begin{array}{c}\text { M.tb } \\
\text { CDCI55I }\end{array}$ & wt & $\mathrm{C} \rightarrow \mathrm{T}$ & wt & wt & wt & wt & wt & wt & $\begin{array}{c}\mathrm{T} \rightarrow \mathrm{C}, \mathrm{T} \rightarrow \mathrm{C}, \\
\mathrm{A} \rightarrow \mathrm{C}\end{array}$ \\
\hline $\begin{array}{c}\text { M.tb } \\
\text { H37Rv }\end{array}$ & wt & wt & wt & wt & wt & wt & wt & wt & wt \\
\hline
\end{tabular}

a SNP position = base position according to the numbering of the $\mathrm{H} 37 \mathrm{Rv}$ genome [18]

$\mathrm{b}$ adalalkA coding sequence is on the minus strand

c isolates from CAR that harbour variations at codon 79 and 337 in ada/alkA, 8/8 isolates sequenced

$\mathrm{d}$ isolates from CAR that harbour variations at codon 337 in adalalkA, 5/25 isolates sequenced

e $M$. bovis isolate from CAR sequenced (one isolate)

CAR, Central African Republic; M.bv, Mycobacterium bovis ; M.tb, Mycobacterium tuberculosis ; wt, wild type (H37Rv).

by spoligotyping). It is also absent from the M. bovis BCG Pasteur strain. Denamur et al. [11] demonstrated horizontal transfer of DNA repair genes between $E$. coli strains and showed that this led to the appearance of mutator phenotypes. Our SNP analysis of the ada/alkA DNA region excludes this possibility for the Amber variation. All $M$. tuberculosis strains carrying the Amber variant in our study population harbour the same SNPs; these SNPs are different from those found in M. bovisAF2122. This argues strongly against horizontal transfer of a region comprising the entire ada/alka gene. Therefore, the Amber variation probably occurred more than once independently and thus constitutes a case of convergent evolution. The acquisition of this variation may confer a selective advantage on the strain.

In several bacteria, the Ada and AlkA proteins are encoded by two distinct genes. The putative ada/alkA gene of $M$. tuberculosis is similar to the ada and alkA genes of E. coli, and is likely to be a fusion of the two genes [14]. Interestingly, the non-sense mutation we described in CAR isolates and in M. bovis AF2122 affects the Ada part of the gene. Presumably, the Amber mutation inactivates the
ada/alkA fused gene and results in a mutator phenotype. Indeed, inactivation of this gene results in an increased mutation frequency in M. tuberculosis without any growth impairment in vivo [7]. Thus, the naturally occurring ada/ alkA mutants we report here may have the advantage of a high mutation rate without any associated cost in vivo. Alternatively, the production of a truncated Ada protein may constitutively activate adaptive responses, as has been demonstrated in E. coli [15]. In particular, it may provide an improved response to stress in vivo, for instance in the phagosome of activated macrophages [16].

\section{Conclusion}

An Amber stop-codon in ada/alkA was detected in some M. tuberculosis Haarlem isolates from CAR and also in $M$. bovis strain AF2122. This Amber variation appears not to have spread by horizontal gene transfer; this could be a case of convergent evolution between $M$. tuberculosis and M. bovis. This suggested that acquisition of the variation may confer a selective advantage. The ada/alkA genetic locus of $M$. tuberculosis has been implicated in mutator phenotype expression [7]. The variant we report may therefore contribute to adaptation to environmental 


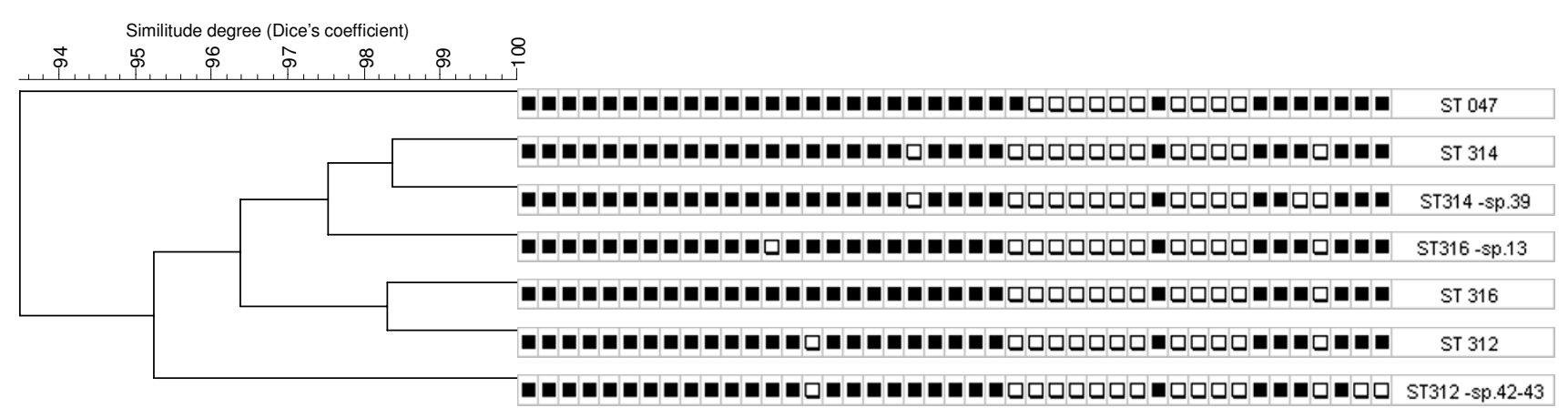

Figure I

Dendrogram of the various spoligopatterns of strains harbouring adalalkA variations at codon 337 or 337 and 79.

changes. In addition, we describe polymorphisms in DNA repair genes in $M$. tuberculosis isolates and these could be used for strain characterization.

\section{Methods}

\section{Strains analyzed}

The collection of strains isolated in the Central African Republic was previously described in Nouvel et al. [8]. Briefly, it includes 55 MDR Mycobacterium tuberculosis strains from different patients and 194 non-MDR strains

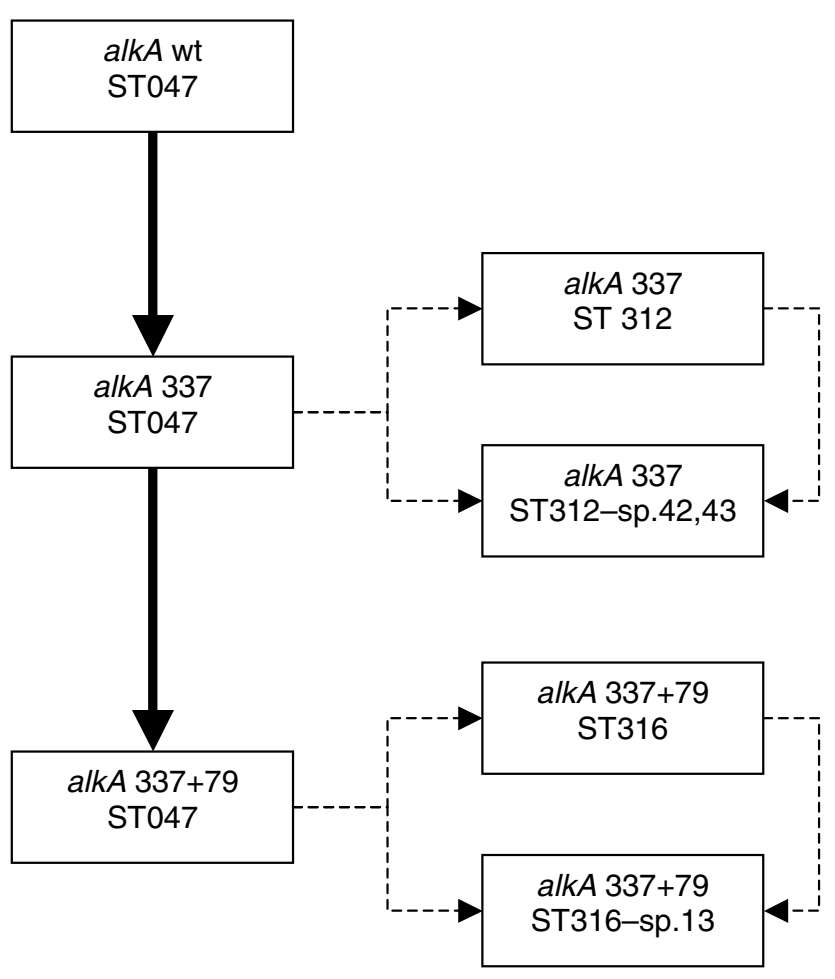

Figure 2

Probable emergence of adalalkA variants. from the cohort studied by Espinal et al. [9] for which a subculture was obtained (192 M. tuberculosis and $2 \mathrm{M}$. bovis strains). Spoligotyping, a method for typing strains of $M$. tuberculosis complex, was performed as previously described $[2,17]$. Spoligopatterns are identified by Shared Type number (ST) according to spolDB3 nomenclature [13].

\section{Sequences of ada/alkA and ogt}

Primers were designed to amplify putative mut genes: ogt (5'-CAGCGCTCGCTGGCGCC -3', 5'-GACTCAGCCGCTCGCGA-3'), and ada/alkA (5'-AGCCGCGTAGGTAACCT-3', 5'-TGCTCGAGCATCCGCAG-3') and (5'-CGCATGCAGACCGCCCG-3', 5'-CACTGCACGTTGCCGAC-3').

DNA sequences of the amplified fragments were determined directly by using the dideoxy chain-termination method with the Big Dye Terminator Cycle Sequencing Kit (Perkin Elmer Applied Biosystems, Courtaboeuf, France) on a GeneAmp polymerase chain reaction (PCR) system 9600 (Perkin Elmer) and run on a DNA analysis system model3100 (Applied Biosystems).

Sequences of genes from M. tuberculosis H37Rv, MT210 and CDC1551, and M. bovis AF2122 were obtained from published sequences $[14,18,19]$ available on the TIGR web site [20].

\section{Computer-assisted analysis of dendrograms}

Autoradiographs were scanned, and the resulting spoligotype data for each mycobacterial isolate was analysed using the Windows version of the computer-assisted BioNumerics software (Applied Maths, Kortrijik, Belgium). Each positive spot was defined as a band. The software then clustered strains with the same spoligotyping patterns. Dendrograms were constructed for the spoligotypes according to degree of similitude (Dice's coefficient) and comparison with known spoligotypes [13,21,22]. 


\section{Comparison of regions flanking ada/alkA}

A $20 \mathrm{~kb}$ DNA region comprising the ada/alkA coding sequence in $M$. tuberculosis $\mathrm{H} 37 \mathrm{Rv}$ was aligned with the corresponding regions in M. bovis AF2122 [19], M. tuberculosis CDC1551, and M. tuberculosis MT210 to identify variations: 9 SNPs were found. Primers were designed to correspond to these sequences (as described above). $M$. tuberculosis H37Rv, M. bovis BCG Pasteur and 16 strains from Bangui (including $2 \mathrm{M}$. bovis strains according to biochemical and spoligotyping markers) were sequenced for these SNPs. A DNA parsimony analysis was used to generate a phylogenetic tree.

\section{Abbreviations \\ CAR : Central African Republic}

\section{M. : Mycobacterium}

MDR : Multidrug resistant

SNP : Single Nucleotide Polymorphism

ST : Shared Type

TB : tuberculosis

\section{Authors' contributions}

LXN carried out the molecular marker study, analyzed results, participated in DNA sequencing, sequence alignment work, and drafted the manuscript. TDV participated in the analysis of results and helped to draft the manuscript. EKK provided genomic DNA of CAR isolates, conducted epidemiological studies and contributed to the analysis of results. JR carried out DNA sequencing and participated in the analysis of results. BG conceived the study, participated in its design and coordination and helped draft the manuscript. All authors have read and approved the final manuscript.

\section{Acknowledgements}

This work received support from the E.C. grant VACSIS (ICA4-CT-200210052) and of the Louis D. award from the French Academy of Science

This article is dedicated to the memory of Eric Kassa-Kelhembo, head of the mycobacterial laboratory in Institut Pasteur of Bangui, who was killed during a mission in CAR as part of the fight against tuberculosis.

\section{References}

I. Dye C, Scheele S, Dolin P, Pathania V, Raviglione MC: Consensus statement. Global burden of tuberculosis: estimated incidence, prevalence, and mortality by country. WHO Global Surveillance and Monitoring Project. J Am Med Assoc 1999, 282:677-86.

2. Kamerbeek J, Schouls L, Kolk A, van Agterveld M, van Soolingen D, Kuijper S, Bunschoten A, Molhuizen H, Shaw R, Goyal M, van Embden $\mathrm{J}$ : Simultaneous detection and strain differentiation of Mycobacterium tuberculosis for diagnosis and epidemiology. J Clin Microbiol 1997, 35:907-14.
3. Kremer K, van Soolingen D, Frothingham R, Haas WH, Hermans PW, Martin C, Palittapongarnpim P, Plikaytis BB, Riley LW, Yakrus MA, Musser JM, van Embden JD: Comparison of methods based on different molecular epidemiological markers for typing of Mycobacterium tuberculosis complex strains: interlaboratory study of discriminatory power and reproducibility. J Clin Microbiol 1999, 37:2607-18.

4. Sreevatsan S, Pan X, Stockbauer KE, Connell ND, Kreiswirth BN, Whittam TS, Musser JM: Restricted structural gene polymorphism in the Mycobacterium tuberculosis complex indicates evolutionarily recent global dissemination. Proc Natl Acad Sci USA 1997, 94:9869-74.

5. Supply P, Warren RM, Banuls AL, Lesjean S, Van Der Spuy GD, Lewis LA, Tibayrenc M, Van Helden PD, Locht C: Linkage disequilibrium between minisatellite loci supports clonal evolution of Mycobacterium tuberculosis in a high tuberculosis incidence area. Mol Microbiol 2003, 47:529-38.

6. Rad ME, Bifani P, Martin C, Kremer K, Samper S, Rauzier J, Kreiswirth B, Blazquez J, Jouan M, van Soolingen D, Gicquel B: Mutations in putative mutator genes of Mycobacterium tuberculosis strains of the W-Beijing family. Emerg Infect Dis 2003, 9:838-45.

7. Durbach SI, Springer B, Machowski EE, North RJ, Papavinasasundaram KG, Colston MJ, Bottger EC, Mizrahi V: DNA Alkylation Damage as a Sensor of Nitrosative Stress in Mycobacterium tuberculosis. Infect Immun 2003, 71:997-I000.

8. Nouvel LX, Kassa-Kelembho E, Dos Vultos T, Zandanga G, Rauzier J, Lafoz C, Martin C, Blazquez J, Talarmin A, Gicquel B: Multidrugresistant Mycobacterium tuberculosis, Bangui, Central African Republic. Emerg Infect Dis 2006, I 2: | 454-6.

9. Espinal MA, Laszlo A, Simonsen L, Boulahbal F, Kim SJ, Reniero A, Hoffner S, Rieder HL, Binkin N, Dye C, Williams R, Raviglione MC: Global trends in resistance to antituberculosis drugs. World Health Organization-International Union against Tuberculosis and Lung Disease Working Group on Anti-Tuberculosis Drug Resistance Surveillance. N EnglJ Med 200I, 344: I 294-303.

10. Medigue C, Rouxel T, Vigier P, Henaut A, Danchin A: Evidence for horizontal gene transfer in Escherichia coli speciation. J Mol Biol 1991, 222:85I-6.

II. Denamur E, Lecointre G, Darlu P, Tenaillon O, Acquaviva C, Sayada C, Sunjevaric I, Rothstein R, Elion J, Taddei F, Radman M, Matic I: Evolutionary implications of the frequent horizontal transfer of mismatch repair genes. Cell 2000, 103:71I-2I.

12. Mardassi H, Namouchi A, Haltiti R, Zarrouk M, Mhenni B, Karboul A, Khabouchi N, Gey van Pittius NC, Streicher EM, Rauzier J, Gicquel B, Dellagi K: Tuberculosis due to resistant Haarlem strain, Tunisia. Emerg Infect Dis 2005, I I:957-6I.

13. Sola C, Filliol I, Gutierrez MC, Mokrousov I, Vincent V, Rastogi N: Spoligotype database of Mycobacterium tuberculosis: biogeographic distribution of shared types and epidemiologic and phylogenetic perspectives. Emerg Infect Dis 200I, 7:390-6.

14. Mizrahi V, Andersen SJ: DNA repair in Mycobacterium tuberculosis. What have we learnt from the genome sequence? Mol Microbiol 1998, 29: | 33|-9.

15. Landini P, Volkert MR: Regulatory responses of the adaptive response to alkylation damage: a simple regulon with complex regulatory features. J Bacteriol 2000, I82:6543-9.

16. Russel DG: Mycobacterium and the seduction of the macrophage. In Mycobacteria: Molecular biology and virulence Edited by: Ratledge C, Dale JW. London, Blackwell Science; 1999:37I-388.

17. Dale JW, Brittain D, Cataldi AA, Cousins D, Crawford JT, Driscoll J, Heersma H, Lillebaek T, Quitugua T, Rastogi N, Skuce RA, Sola C, Van Soolingen D, Vincent V: Spacer oligonucleotide typing of bacteria of the Mycobacterium tuberculosis complex: recommendations for standardised nomenclature. Int J Tuberc Lung Dis 200I, 5:216-9.

18. Cole ST, Brosch R, Parkhill J, Garnier T, Churcher C, Harris D, Gordon SV, Eiglmeier K, Gas S, Barry CE 3rd, Tekaia F, Badcock K, Basham D, Brown D, Chillingworth T, Connor R, Davies R, Devlin K, Feltwell T, Gentles S, Hamlin N, Holroyd S, Hornsby T, Jagels K, Krogh A, McLean J, Moule S, Murphy L, Oliver K, Osborne J, Quail MA, Rajandream MA, Rogers J, Rutter S, Seeger K, Skelton J, Squares R, Squares S, Sulston JE, Taylor K, Whitehead S, Barrell BG: Deciphering the biology of Mycobacterium tuberculosis from the complete genome sequence. Nature 1998, 393:537-44.

19. Garnier T, Eiglmeier K, Camus JC, Medina N, Mansoor H, Pryor M, Duthoy S, Grondin S, Lacroix C, Monsempe C, Simon S, Harris B, 
Atkin R, Doggett J, Mayes R, Keating L, Wheeler PR, Parkhill J, Barrell BG, Cole ST, Gordon SV, Hewinson RG: The complete genome sequence of Mycobacterium bovis. Proc Natl Acad Sci USA 2003, 100:7877-82.

20. The Institute for Genomic Research web site [http:// www.tigr.org]

21. Filliol I, Driscoll JR, van Soolingen D, Kreiswirth BN, Kremer K, Valetudie G, Dang DA, Barlow R, Banerjee D, Bifani PJ, Brudey K, Cataldi A, Cooksey RC, Cousins DV, Dale JW, Dellagostin OA, Drobniewski F, Engelmann G, Ferdinand S, Gascoyne-Binzi D, Gordon M, Gutierrez MC, Has WH, Heersma H, Kassa-Kelembho E, Ho ML, Makristathis A, Mammina C, Martin G, Mostrom P, Mokrousov I, Narbonne V, Narvskaya O, Nastasi A, Niobe-Eyangoh SN, Pape JW, RasolofoRazanamparany V, Ridell M, Rossetti ML, Stauffer F, Suffys PN, Takiff $\mathrm{H}$, Texier-Maugein J, Vincent V, de Waard JH, Sola C, Rastogi N: Snapshot of moving and expanding clones of Mycobacterium tuberculosis and their global distribution assessed by spoligotyping in an international study. J Clin Microbiol 2003, 41:1963-70.

22. Filliol I, Driscoll JR, Van Soolingen D, Kreiswirth BN, Kremer K, Valetudie G, Anh DD, Barlow R, Banerjee D, Bifani PJ, Brudey K, Cataldi A, Cooksey RC, Cousins DV, Dale JW, Dellagostin OA, Drobniewsk F, Engelmann G, Ferdinand S, Gascoyne-Binzi D, Gordon M, Gutierrez MC, Haas WH, Heersma H, Kallenius G, Kassa-Kelembho E, Koivula T, Ly HM, Makristathis A, Mammina C, Martin G, Mostrom P, Mokrousov I, Narbonne V, Narvskaya O, Nastasi A, Niobe-Eyangoh SN, Pape JW, Rasolofo-Razanamparany V, Ridell M, Rossetti ML, Stauffer F, Suffys PN, Takiff $H$, Texier-Maugein J, Vincent V, De Waard $\mathrm{JH}$, Sola C, Rastogi N: Global Distribution of Mycobacterium tuberculosis Spoligotypes. Emerg Infect Dis 2002, 8:1347-9.

\section{Publish with Bio Med Central and every scientist can read your work free of charge}

"BioMed Central will be the most significant development for disseminating the results of biomedical research in our lifetime. "

Sir Paul Nurse, Cancer Research UK

Your research papers will be:

- available free of charge to the entire biomedical community

- peer reviewed and published immediately upon acceptance

- cited in PubMed and archived on PubMed Central

- yours - you keep the copyright

Submit your manuscript here:

http://www.biomedcentral.com/info/publishing_adv.asp
BioMedcentral 